\title{
Risks of dam construction for South American river dolphins: a case study of the Tapajós River
}

\author{
Heloise J. Pavanato ${ }^{1, *}$, Gabriel Melo-Santos ${ }^{2}$, Danielle S. Lima ${ }^{1,3}$, \\ Marcela Portocarrero-Aya ${ }^{4}$, Mariana Paschoalini ${ }^{1,5}$, Federico Mosquera ${ }^{6}$, \\ Fernando Trujillo ${ }^{6}$, Rafael Menese ${ }^{1,7}{ }^{,}$Miriam Marmontel $^{1}$, Cláudio Maretti ${ }^{8,9}$
}
${ }^{1}$ Research Group on Amazonian Aquatic Mammals, Mamirauá Institute for Sustainable Development, 2584 Estr. do Bexiga, 69553-225, Tefé, AM, Brazil
${ }^{2}$ Biology and Conservation of Amazon Aquatic Mammals, Federal University of Pará,
Graduate Program of Theory and Research of Behavior, 01 Augusto Correa, 66075-110, Guamá, PA, Brazil
${ }^{3}$ Laboratory of Mastozoology, Institute of Scientific and Technological Research of the State of Amapá, Rod. Juscelino Kubitschek km. 10, 68901-025, Macapá, AP, Brazil
${ }^{4}$ Instituto de Investigación de Recursos Biológicos Alexander von Humboldt, 15-09 Callle 28A, Bogota DC, Colombia
${ }^{5}$ Laboratory of Behavioral Ecology and Bioacoustics, Federal University of Juiz de Fora, José Lourenço Kelmer, 36036-330, Juiz de Fora, MG, Brazil
${ }^{6}$ Omacha Foundation, 23-28 Calle 86A, Bogota DC, Colombia
${ }^{7}$ Biodiversity Department, State University of Maranhão, Cidade Universitária Paulo VI, 66055-970, São Luís, Maranhão, Brazil
${ }^{8}$ WWF Living Amazon Initiative, Edificio Jade Office SGCV Lote 15, S/N, Zona Industrial Guará, 71215-650 Brazil, Brasília DC, Brazil

\begin{abstract}
${ }^{9}$ Present address: Diretoria de Ações Socioambientais e Consolidação Territorial em Unidades de Conservação/Brazilian Ministry of Environment, EQSW 103/104 Bloco C, Complexo Administrativo Setor Sudoeste, 700670-350, Brasília DC, Brazil
\end{abstract}

\begin{abstract}
River dolphins are strongly affected by the construction of hydroelectric dams. Potential isolation in subpopulations above and below such dams and the resulting low genetic variability of these subpopulations can cause extinction at a local level. Here we aimed to estimate density and population size of South American river dolphins (boto Inia geoffrensis and tucuxi Sotalia fluviatilis), map their distribution, and estimate potential biological removal (PBR) limits in order to evaluate the effects of population fragmentation between planned dams in the Tapajós River, Amazonian basin, Brazil. Boat-based surveys were conducted following a line transect sampling protocol covering different dolphin habitats in 2 stretches of the river divided by rapids. The mark-recapture distance sampling method was applied to account for animals missed on the trackline. After the estimation of population sizes by habitat, PBR was calculated. The farthest upriver sighting of tucuxis was close to the São Luiz do Tapajós rapids, whereas the farthest upriver sighting of botos was upstream of the rapids, suggesting that botos move upstream through the rapids. Estimated abundance of tucuxis (3372 ind., CV = 0.38) was twice as high as that estimated for botos (1815 ind., CV = 0.4). The PBR ranged from 11 to 18 ind. for boto and 21 to 34 for tucuxi. Throughout this study, we identified low abundances of river dolphins compared to other Amazon rivers. Boto may not be sustainable at a population level, due primarily to population fragmentation which would result from the construction of the proposed dams. Precautionary measures are urgently needed before construction of dams begins in the Tapajós River.
\end{abstract}

KEY WORDS: Cetacean abundance - Distance sampling $\cdot$ Inia geoffrensis $\cdot$ Sotalia fluviatilis Extinction · IUCN Red List Category · Marine mammal · Population modeling

\section{INTRODUCTION}

The building of dams and barrages to enable the generation of hydroelectric energy and the creation

*Corresponding author: helopavanato@gmail.com

$\S_{\text {Corrections were made after publication. For details see }}$ www.int-res.com/articles/esr2017/32/n032p041.pdf

This version: January 25, 2017 of irrigation canals has impacted river systems worldwide. Dams transform riverine habitats, disrupt water flow, increase sediment loads upstream, change thermal conditions and nutrient balance, inundate tracts

() The authors 2016. Open Access under Creative Commons by Attribution Licence. Use, distribution and reproduction are unrestricted. Authors and original publication must be credited.

Publisher: Inter-Research · www.int-res.com 
of land, and increase the impact of sewage and industrial effluents (Dudgeon 1992, Kondolf 1997, Rosenberg et al. 1997, McCully 2001, Sabir et al. 2013, Kondolf et al. 2014). The main mechanisms driving these impacts are the modification of rapids and construction of locks (Reeves \& Leatherwood 1994). Aquatic fauna is directly affected by disruption of fish migration (Sioli 1984, Dudgeon 1992, FAO 2001, Luz-Agostinho et al. 2008), which may lead to breeding failure (Dudgeon 1992), and low levels of dissolved oxygen, which reduce habitat availability.

As top predators, river dolphins are likely affected by dam construction. Possible impacts on river dolphin populations are reduced prey fish diversity and abundance (Luz-Agostinho et al. 2008), and possible displacement to unusual areas while searching for prey. In addition, river dolphins may be affected at a population level by the formation of subpopulations and/or reduction in their distribution range (Reeves \& Leatherwood 1994, Smith \& Reeves 2012, Braulik et al. 2015). Dams and barrages divide rivers, disrupting dolphin movements upstream and downstream, isolating individuals above and below dams and reservoirs. This process leads to the isolation of subpopulations with low genetic variability (da Silva \& Martin 2010, Gravena et al. 2014), which can cause local extinction.

South American river dolphins are widely distributed in the Amazon, Orinoco, and Tocantins River basins (Best \& da Silva 1993, Santos et al. 2012, Hrbek et al. 2014, Santos et al. 2014, Melo-Santos et al. in press). Along these rivers, dam construction has already been demonstrated to have an effect on populations of boto (genus Inia) and tucuxi Sotalia fluviatilis. For example, a hydroelectric dam built in the Caroni River, a tributary of the Orinoco River in Venezuela, is apparently the cause of the decline in I. geoffrensis in that region (Portocarrero-Aya et al. 2010). In the Brazilian Amazon, 2 dams built on the Madeira River caused the fragmentation of an I. boliviensis population into 3 subpopulations (Gravena et al. 2014). In the Tocantins River basin, subpopulations of $I$. araguaiaensis were isolated upstream in a reservoir as well as downstream in the Tocantins River (Araújo \& Wang 2012, Araújo \& da Silva 2014, N. Ristau unpubl. data).

In the Tapajós River basin (Amazon basin, Brazil), plans are underway for the construction of 3 large hydroelectric dams in the main course of the river. The first of these dams is planned to be built upstream from the rapids of São Luiz do Tapajós (04 ${ }^{\circ}$ 34' 5.86" S, 56 16' 33.16"W) in 2018. The planning order estimates the construction of the Jatobá dam $\left(05^{\circ} 11^{\prime} 50.3^{\prime \prime} \mathrm{S}, 56^{\circ} 55^{\prime} 10.42^{\prime \prime} \mathrm{W}\right)$ by 2019 and the
Chacorão dam $\left(06^{\circ} 3^{\prime} 22.80^{\prime \prime} \mathrm{S}, 58^{\circ} 18^{\prime} 33.84^{\prime \prime} \mathrm{W}\right)$ (International Rivers 2015) with no date available. In addition to these mega-constructions, other small dams are planned for tributaries of the Tapajós, along with the implementation of waterways to transport soybeans between Brazilian states (Fearnside 2015).

Given the current scenario of hydroelectric dams projected for the Amazon River basin, especially those in the Tapajós River, it is relevant to recall that Asian river dolphins experienced a similar situation and are currently highly endangered. Isolated subpopulations of bhulan Platanista gangetica gangetica and susu $P$. g. minor have become extinct or have experienced critical population reductions as a result of the barrier effects of dams and barrages (Smith 1998, Reeves et al. 2000, Paudel et al. 2015). While bhulan and susu are currently classified as Endangered by the International Union for Conservation of Nature (IUCN; Smith \& Braulik 2012), the baiji Lipotes vexillifer is currently classified as Critically Endangered by the IUCN (Smith et al. 2008) and as 'possibly extinct' by the Society for Marine Mammalogy. The baiji historically occurred in the middle and lower reaches of the Yangtze River. In 2003, the species appeared limited to several short sections of the river (Zhang et al. 2003). Furthermore, Turvey et al. (2007) carried out multi-vessel visual and acoustic surveys throughout the historical range of the baiji and failed to find any evidence of its occurrence, suggesting that the species is now extinct. This is probably the first global extinction of a cetacean species caused by human actions (construction of dams, pollution, loss of habitat, predatory fishery, etc.), and it represents the loss of a whole mammalian evolutionary lineage (Dudgeon 2005, Turvey et al. 2007).

Similar to Asian river dolphins, the ecology of South American river dolphins is not fully understood. Estimates for demographic parameters related to reproduction, migration, survival, and mortality are lacking, which has prevented a correct categorization of the species as to their conservation status, hindering conservation actions. Official reports on the river dolphins inhabiting the Tapajós River are scant, contributing to the high level of uncertainty about the species' status. Regarding occurrence, I. geoffrensis was recorded from the vicinity of the city of Santarém, at the mouth of the Tapajós River $\left(02^{\circ} 25^{\prime} 08^{\prime \prime} \mathrm{S}, 54^{\circ} 43^{\prime} 50^{\prime \prime} \mathrm{W}\right)$, to São Martins $\left(06^{\circ} 9^{\prime} 12.89^{\prime \prime} \mathrm{S}, 57^{\circ} 36^{\prime} 50.62^{\prime \prime} \mathrm{W}\right)$, in the middle reaches of the Tapajós River. S. fluviatilis was reported from the mouth of the Tapajós River $\left(02^{\circ} 28^{\prime} 16^{\prime \prime} \mathrm{S}, 54^{\circ} 59^{\prime} 4^{\prime \prime} \mathrm{W}\right)$ to the vicinity of the city of Itaituba (04 $\left.17^{\prime} 9^{\prime \prime} \mathrm{S}, 5^{\circ} 58^{\prime} 8^{\prime \prime} \mathrm{W}\right)$, and probably occurs up to the rapids close to the town of São Luiz do 
Tapajós (Melo-Santos et al. in press). Nevertheless, the limit of occurrence of both species is unknown, and no density or population size estimates are available (Secchi 2012, Reeves et al. 2013).

Therefore, our objective was to estimate density and abundance parameters of South American river dolphins and map their distribution in the Tapajós River. To understand how river dolphin populations would behave in the fragmentation scenario, we used a population limit analysis to calculate the number of individuals that could be removed from the populations without affecting their net productivity. Finally, we discuss the impact of hydroelectric dams on South American river dolphins, with respect to primary and secondary risks.

\section{MATERIALS AND METHODS}

\section{Study area}

The Tapajós River basin is the fifth largest basin that discharges into the Amazon River, and covers $7 \%$ of the total Amazon basin (Goulding et al. 2003). The basin extends over $2700 \mathrm{~km}$ (Goulding et al. 2003), and its width may exceed $20 \mathrm{~km}$ in some parts. The flooding season in the upper Tapajós River begins in September, while the lower parts of the river flood an average of 3 mo later. The high water level peak occurs in March in the upper and middle Tapajós, and in May or June in the lower reaches due to the influence of the Amazon River. Between the flooded and dry seasons, the water level can vary by up to $9 \mathrm{~m}$. The major cause of the seasonal change is the rainy period, although the lower Tapajós is also influenced by the gravitational tide (Sioli 1984).

The Tapajós is a clear-water river with 1.10 to $4.30 \mathrm{~m}$ of transparency (Sioli 1984). Although the river current is weak, rapids are found along the main course and in the Juruena and Teles Pires tributaries (Sioli 1984, Junk et al. 2012). The largest rapids in the Tapajós River basin are located near the town of São Luiz do Tapajós (Sioli 1984, Goulding et al. 2003). However, migratory fishes move upstream and downstream (Goulding et al. 2003) along with river dolphins during the flooded period, as suggested by Melo-Santos et al. (in press) and as observed by members of the local community.

\section{Sampling protocol}

We conducted boat-based surveys in the Tapajós River from 28 July to 6 August 2014, during the falling water season. We used 2 sighting platforms: a regional double-decker boat $7 \mathrm{~m}$ above the water surface, and a small outboard-motor-powered boat $<1 \mathrm{~m}$ above the water surface. Both vessels traveled at a maximum speed of $12 \mathrm{~km} \mathrm{~h}^{-1}$ and covered 2 stretches: (1) lower Tapajós River: from the confluence between the Tapajós and Amazon Rivers (city of Santarém, Pará State) to the São Luiz do Tapajós rapids, and (2) middle Tapajós River: from the planned Jatobá dam construction site to the city of Jacareacanga (Pará State) (Fig. 1). In the second stretch, only the smaller boat was used due to the river conditions (presence of rapids or rocks, and shallow depths). We included vessel type as a variable in the analysis to account for possible sighting bias.

We followed the line transect sampling protocol (Buckland et al. 2001) with a combination of transects placed $100 \mathrm{~m}$ parallel to the river margin and crosschannel transects, crossing from one margin to another in a zigzag pattern with angles between $40^{\circ}$ and $90^{\circ}$ (perpendicular to the margin), to cover the different dolphin habitats (Vidal et al. 1997, Martin \& da Silva 2004, Martin et al. 2004, Gomez-Salazar et al. 2012a, Pavanato et al. in press). Average length of both types of transect was $2.5 \mathrm{~km}$. In the presence of rocks and at shallow depths, we navigated at distances greater than $100 \mathrm{~m}$ from the margin (median = $100 \mathrm{~m}$, mean $=128 \mathrm{~m}$, maximum distance $=626 \mathrm{~m}$ ). Whenever feasible (depending on presence of rocks and shallows based on the captain's assessment), we crossed the river channel after conducting 4 marginal transects (approx. $10 \mathrm{~km}$ ).

To enable the estimation of the detection probability in the trackline (Laake \& Borchers 2004, GomezSalazar et al. 2012a, Pavanato et al. in press), 2 independent platforms were used at the bow and stern of the regional double-decker boat (fore and aft platforms). At each platform, 2 observers, positioned at port and starboard, actively searched for dolphins from $0^{\circ}$ to $90^{\circ}$ from their perspectives, and a third person recorded the data. Researchers rotated positions every hour in the following order: observer, data recorder, observer, and rest. Communications between the platforms were via radio, whenever necessary (e.g. stern reporting a sighting to the bow team). In the smaller vessel, only 2 researchers were responsible for the sightings and data record, and, thus, we were not able to implement a double-platform configuration.

At the beginning of each transect, or whenever a change occurred, environmental conditions were recorded: river state (0 to 3 , increasing turbulence scale), glare (0 to 3 , increasing intensity scale), visi- 


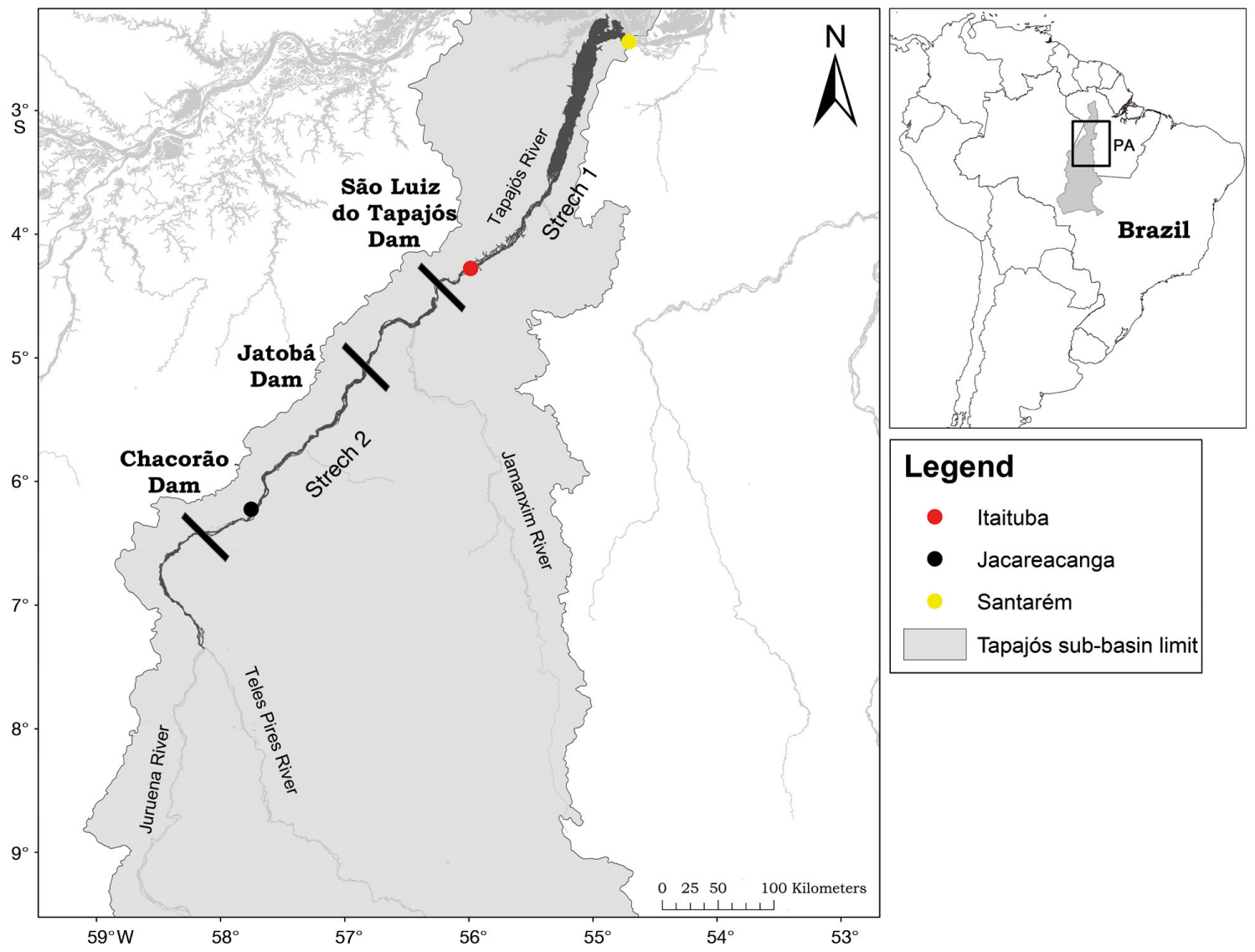

Fig. 1. Tapajós River basin, Brazil, highlighting the 2 stretches surveyed in the Tapajós River: (1) lower Tapajós River, from the confluence between the Tapajós and Amazon Rivers (city of Santarém, yellow dot) to the São Luiz do Tapajós rapids, and (2) middle Tapajós River, from the planned Jatobá dam construction site to the city of Jacareacanga (black dot). PA: Pará

bility (1 to 4, 1 being poor and 4 excellent), and presence of rain. For each sighting, the observers reported the species, group size, presence of calves, sighting angle relative to the trackline, distance from the observer to the dolphin group (estimated by eye), and distance from the dolphin group to the river margin (estimated by eye). The majority of the observers had previous training and experience estimating distances using laser rangefinders.

To account for variability in density of river dolphins as a function of habitat type (Martin \& da Silva 2004, Martin et al. 2004, Gomez-Salazar et al. 2012a, Pavanato et al. in press), sampling was carried out by means of stratification (Buckland et al. 2001, 2004). The strata were defined as in Gomez-Salazar et al. (2012a): main river margin, main river channel (water courses at least $400 \mathrm{~m}$ in width and classified as a basin or sub-basin), channel (water courses no more than $300 \mathrm{~m}$ width generally associated with island and main river systems), island, tributary, lake, and confluence.

\section{Density estimates}

To estimate density and population size of river dolphins following the standard line transect sampling analysis, distances and angles from the observers to the groups were used to calculate the perpendicular distances through basic trigonometric rules (distance sampling, DS; Buckland et al. 2001). For both types of transects, we fitted detection curves using the halfnormal and hazard-rate functions to the perpendicular distances (Buckland et al. 2001). We included covariates that may affect the detection probability using multicovariate DS (MCDS, Marques \& Buckland 2003). For the half-normal function, we have:

$$
g\left(x_{i}\right)=\exp \left(\frac{-x_{i}^{2}}{\sigma_{i}^{2}}\right)
$$

$$
\log \left(\sigma_{i}\right)=\beta_{0}+\beta_{1} \operatorname{cov} l_{i}+\beta_{2} \operatorname{cov} 2_{i}+\ldots+\beta_{n} \operatorname{cov} n_{i}
$$

for $i=1,2, \ldots$, maximum number of observations and $n=1,2, \ldots$, maximum number of covariates (cov), 
where $x$ is the perpendicular distance, $\sigma$ is the scale parameter, $\beta_{0}$ is the intercept, $\beta_{1} \ldots \beta_{n}$ are the coefficients associated with the covariates 'group size' and 'river state' (numeric), and 'visibility' and 'vessel' (factor). We did not include the covariates 'river state' and 'visibility' in the same model due to the collinearity between them.

To account for the animals missed on the trackline $(g(0))$, which corresponds to the detection bias and, sometimes, availability bias of both platforms (Marsh \& Sinclair 1989, Laake \& Borchers 2004), we used the mark-recapture (MR) method coupled with DS (MRDS; Laake \& Borchers 2004, Gomez-Salazar et al. 2012a).

For the fore and aft platforms, a binary sighting history was generated: 1 if the group was detected and 0 if the group was not detected. Through logistic regression, it was possible to estimate the detection probability for both platforms (Laake \& Borchers 2004). In order to avoid negative bias on $\hat{N}$ (estimated abundance), we used independent configuration with point independence (Laake \& Borchers 2004) in the MRDS. We inserted distance $(x)$ and group size $(s)$ as covariates in the logistic model, as follows:

$$
\begin{gathered}
g(X, s)=g_{1}(X, s)+g_{2}(X, s)-\left(g_{1}(X, s) g_{2}(X, s)\right) \\
g_{1,2}(X, s)=\frac{\exp \left(\beta_{0}+\beta_{1} X+\beta_{2} s\right)}{1+\exp \left(\beta_{0}+\beta_{1} X+\beta_{2} s\right)}
\end{gathered}
$$

where $g_{1,2}(X, S)$ corresponds to the joint probability of both platforms detecting the groups, $g_{1}(X, S)$ and $g_{2}(X, S)$ correspond to the detection probability for the fore (observer 1) and aft (observer 2) platforms, respectively, $\beta_{0}$ is the intercept, and $\beta_{1}$ and $\beta_{2}$ are the coefficients of the covariates 'distance' and 'group size.' Whenever the perpendicular distances and group size differed between platforms, we used data measured by the fore platform.

We tested different combinations of covariates in the DS and MR models, and applied Akaike's information criterion (AIC) to choose between candidate models and carry out parameter inference (Burnham \& Anderson 2002). Density ( $\hat{D})$ by species and strata was obtained by the Horvitz-Thompson estimator (Horvitz \& Thompson 1952):

$$
\hat{D}=\frac{E(s)}{2 W_{\text {strata }} L_{\text {strata }}} \sum_{j=1}^{n} \frac{1}{g(x, s)}
$$

where $E(s)$ is the expected group size, $w$ is the maximum width by stratum, $L$ is the transect length by stratum, and $n$ is the number of detected groups. Since we were not able to maintain the established distance of $100 \mathrm{~m}$ for every transect, we visually inspected the distance frequencies to define the maximum distance that might be used as the truncation distance. Due to the uniformity of frequencies regarding the distance classes $0-50,50-100$, and 100-150, distances were truncated at $150 \mathrm{~m}$ for river margin, channel, island, tributary, and lake. For river channel, distances beyond $300 \mathrm{~m}$ were discarded because of measurement inaccuracy.

Finally, we obtained abundance by strata $\left(\hat{N}_{\text {strata }}\right)$ through:

$$
\hat{N}_{\text {strata }}=\hat{D}_{\text {strata }} A_{\text {strata }}
$$

where $A$ corresponds to the study area $\left(\mathrm{km}^{2}\right)$.

We computed the model variance following Innes et al. (2002). The variation coefficient (CV) was derived from $\hat{N} / \sigma$, where $\sigma$ is the standard deviation. The analyses were performed through the mrds package (Laake et al. 2015) and R software (R Core Team 2015).

\section{Fragmentation analysis}

After we computed the overall estimates by stratum and derived total abundance, we calculated an annual mortality limit, known as the potential biological removal (PBR) level, defined by the US Marine Mammal Protection Act in order to achieve population sizes at or above the maximum net productivity level (MNPL; Wade 1998). Populations are considered sustainable if they are estimated to be above 50 to $70 \%$ of their historical population size, which is thought to represent carrying capacity (Gerrodette \& DeMaster 1990, Taylor \& DeMaster 1993).

Here, the limit of how many individuals could be removed from the population annually means the portion that can be removed from the population by mortality events and, most important, by isolation of some individuals due to dam construction (generating subpopulations). We calculated the removal limit for the overall abundance estimates by species as:

$$
\mathrm{PBR}=\hat{N}_{\min } 1 / 2 R_{\max } F_{R}
$$

where $\hat{N}_{\text {min }}$ is the minimum population size estimate of boto and tucuxi in the Tapajós River, $1 / 2 R_{\max }$ corresponds to half the maximum theoretical net productivity rate of the population at a small size (i.e. the annual per capita rate of increase in a population resulting from the difference between reproduction and mortality), and $F_{R}$ is a recovery factor between 0 and 1 to account for potential bias in the data, where 1 corresponds to absence bias. 
In this study, we used $R_{\max }=0.04$ (established for cetaceans when no other specific information is available) and $F_{R}=0.5$ to account for levels of bias in estimation procedures, as recommended by Wade (1998). To account for our uncertainty over abundance, the $10^{\text {th }}, 20^{\text {th }}, 30^{\text {th }}$, and $40^{\text {th }}$ percentiles and mean (median or $50^{\text {th }}$ percentile) of a log-normal distribution were used as $\hat{N}_{\min }$ as follows:

$$
\hat{N}_{\text {min }}=\frac{\hat{N}}{\exp \left\{z \sqrt{\log \left[1+\mathrm{CV}(N)^{2}\right]}\right\}}
$$

where $z$ is the standard normal variate. In this way we were able to estimate possible PBRs with different minimum population sizes from the most $\left(10^{\text {th }}\right.$ percentile) to the least ( $50^{\text {th }}$ percentile) conservative approach.

\section{RESULTS}

Along both stretches (1 and 2), we detected 84 groups of boto and 88 groups of tucuxi, which corresponds to 112 and 160 ind., respectively, over a sampling effort of $577 \mathrm{~km}$. The fore platform detected 50 groups of boto and 53 groups of tucuxi, while the aft platform detected 41 groups of boto and 54 groups of tucuxi. The number of groups detected by both platforms (joint detection) was 15 for boto and 25 for tucuxi.

The farthest upriver sighting of tucuxi was close to the São Luiz do Tapajós rapids, while the farthest upriver sighting of boto was near the city of Jacareacanga, which represents the final sampling point (Fig. 2).

\section{Overall density estimates}

For the DS model, half-normal and hazard rate detection functions with different combinations of covariates resulted in similar adjustments. Based on the AIC, the less parameterized model was chosen for inference (half-normal). Among all models, the detection probability as a function of the group size and distance effects over the MR was the best fitted model (Table 1).

For both species, the MR model showed positive and negative significant effects of group size and distance, respectively, in relation to the detection probability (Table 2). The joint detection probability was higher for tucuxi than for boto, even though both were relatively low (Table 2 , Figs. $3 \& 4$ ). The detection probabilities estimated for the fore (observer 1) and aft (observer 2) platforms by spe-
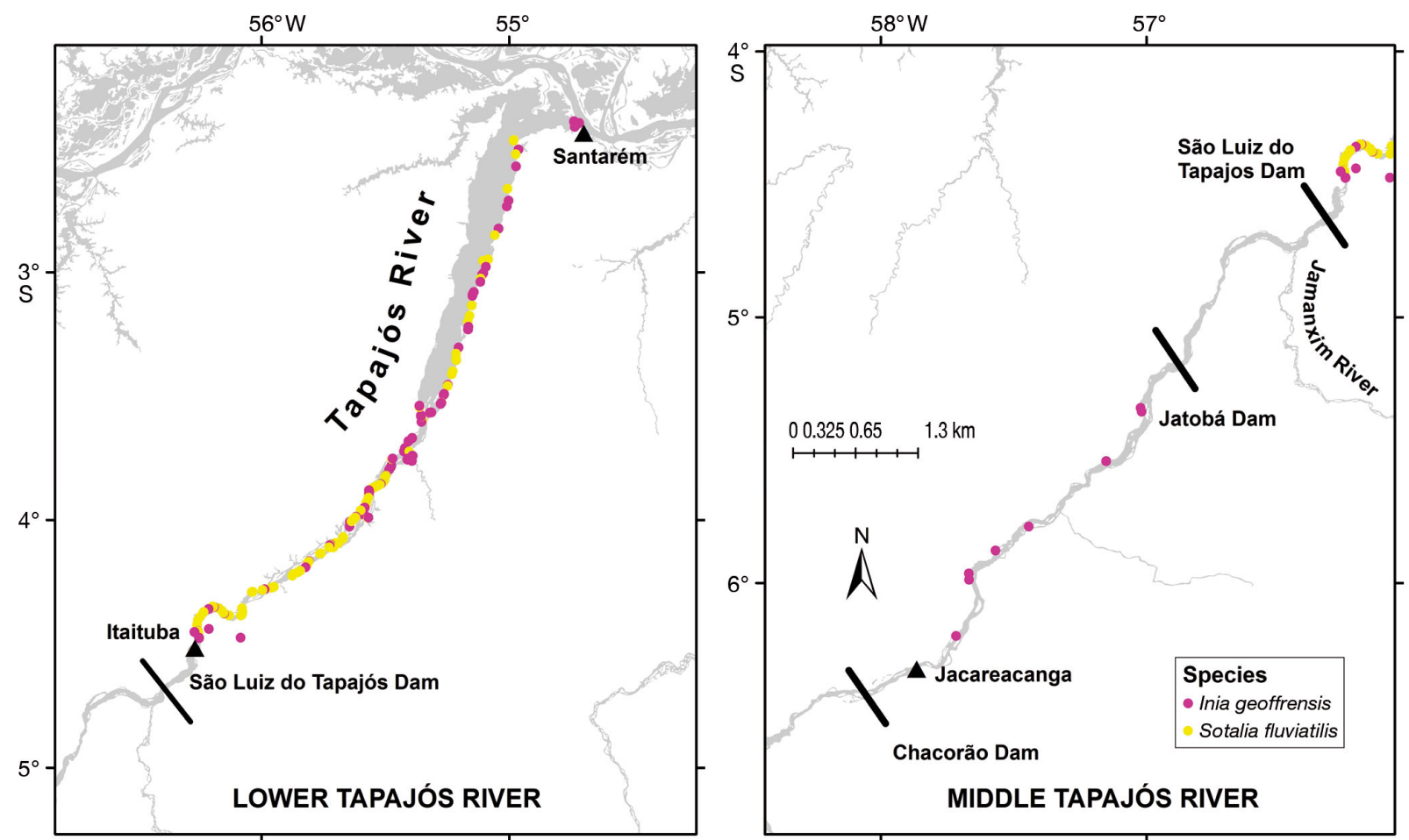

Fig. 2. Sightings of boto Inia geoffrensis (pink dots) and tucuxi Sotalia fluviatilis (yellow dots) along the Tapajós River, Brazil 
Table 1. Distance sampling (DS) and mark-recapture (MR) models for boto Inia geoffrensis and tucuxi Sotalia fluviatilis adjusted with the hazard rate $(h z)$ and half-normal $(h n)$ distributions and the covariates s: group size, vessel: vessel type, visib: visibility, river: river state, and $x$ : perpendicular distance. Corresponding Akaike's information criterion (AIC) and $\triangle \mathrm{AIC}$ are shown. Models with the vessel covariate were not fitted to tucuxi data because we observed this species in only 1 vessel category. The best fitted model is shown in bold

\begin{tabular}{|c|c|c|c|c|c|}
\hline \multirow[t]{2}{*}{ DS model } & \multirow{2}{*}{$\begin{array}{c}\text { MR } \\
\text { model }\end{array}$} & \multicolumn{2}{|c|}{ Boto } & \multicolumn{2}{|c|}{$\ldots$ Tucuxi } \\
\hline & & AIC & $\triangle \mathrm{AIC}$ & AIC & $\Delta \mathrm{AIC}$ \\
\hline hz (null) & (null) & 916.893 & 20.047 & 1125.220 & 73.897 \\
\hline hz: vessel & (null) & 916.893 & 20.047 & - & - \\
\hline hz: vessel & S & 917.111 & 20.265 & - & - \\
\hline hz: vessel & $x$ & 897.939 & 1.093 & - & - \\
\hline hz (null) & $S+X$ & 896.846 & 0 & 1051.323 & 0 \\
\hline hz: vessel & $S+X$ & 916.893 & 20.047 & - & - \\
\hline hz: vessel + visib. & $S+X$ & 896.846 & 0 & - & - \\
\hline hz: vessel + river & $s+x$ & 896.846 & 0 & - & - \\
\hline hz: visib. & $s+x$ & 896.846 & 0 & 1051.323 & 0 \\
\hline hz: river & $S+X$ & 896.846 & 0 & 1051.323 & 0 \\
\hline hz: vessel + s & $S+X$ & 896.846 & 0 & - & - \\
\hline hn (null) & (null) & 916.893 & 20.047 & 1125.220 & 73.897 \\
\hline hn: vessel & (null) & 916.893 & 20.047 & - & - \\
\hline hn: vessel + visib. & (null) & 917.111 & 20.265 & - & - \\
\hline hn (null) & $s+x$ & 896.846 & $\mathbf{0}$ & 1051.323 & $\mathbf{0}$ \\
\hline hn: vessel & $S+X$ & 896.846 & 0 & - & - \\
\hline hn: vessel + visib. & $S+X$ & 896.846 & 0 & - & - \\
\hline hn: vessel + river & $S+X$ & 896.846 & 0 & - & - \\
\hline hn: visib. & $s+x$ & 896.846 & 0 & 1051.323 & 0 \\
\hline hn: river & $s+x$ & 896.846 & 0 & 1051.323 & 0 \\
\hline hn: vessel $+s$ & $S+X$ & 896.846 & 0 & - & - \\
\hline
\end{tabular}

\section{Fragmentation analysis}

The PBR limit for the overall population size of boto and tucuxi ranged from 11 to 18 and 21 to 34 ind., respectively, for the different $\hat{N}_{\text {min }}$ (Table 4 ). This means that the populations can continue to grow at their MNPL even if these numbers of individuals are removed.

\section{DISCUSSION}

Throughout this study, we confirmed that the distribution range of boto extends to the upper reaches of the Tapajós River, above the São Luiz do Tapajós rapids. We also confirmed the occurrence limit of tucuxi as being downstream from the rapids. In the 2 stretches between rapids surveyed, the overall population size was $1815(\mathrm{CV}=0.4)$ for boto and 3372 (CV = 0.38) for tucuxi. The PBR limits according to the different $\hat{N}_{\text {min }}$ scenarios pointed to low numbers of sustainable human removal (or human-caused mortality) for both populations.

Below, we provide clarification of our modeling assumptions in order to aid in cies evidenced the ability of the observers to detect tucuxi at greater distances $(300 \mathrm{~m})$ when compared with boto $(140 \mathrm{~m})$. In addition, the duplicate detections at $0-50 \mathrm{~m}$ from the trackline were greater than 0.4 for tucuxi, while for boto, probabilities did not exceed 0.2 . In the first $40 \mathrm{~m}$ from the trackline, the aft platform detected fewer botos than the fore platform; for tucuxi, both platforms were able to detect around $80 \%$ of the groups (Figs. $3 \& 4$ ).

According to the MRDS results, the overall abundance of tucuxi (3372 ind., 95\% CI = 1624-7003) was around 2 times larger than that estimated for boto (1815 ind., 95\% CI = 848-3872). This difference arises mainly from the density in the main riverchannel stratum (Table 3). Density of boto in the tributary was substantially higher than the density of tucuxi. Nevertheless, due to the small area of this stratum, a low abundance of boto was estimated (Table 3). In the other strata, density and abundance were similar for both species. We did not observe any river dolphins in lake and confluence strata (Table 3).
Table 2. Statistical summary of the detection probability of boto Inia geoffrensis and tucuxi Sotalia fluviatilis by platform (observers 1 and 2) obtained through the markrecapture model containing the point estimates of parameters, standard error (SE) and coefficient of variation (CV). $S$ : group size, $x$ : perpendicular distance, $g_{1}$ : detection probability of observer 1 (fore platform), $g_{2}$ : detection probability of observer 2 (aft platform), $g_{1,2}$ : joint detection probability between observers 1 and 2

\begin{tabular}{|lrcc|}
\hline Parameter & Estimate & SE & CV \\
\hline Boto & & & \\
Intercept & -0.824 & 0.553 & - \\
$S$ & 0.349 & 0.261 & - \\
$X$ & -0.018 & 0.009 & - \\
$g_{1}$ & 0.402 & 0.095 & 0.214 \\
$g_{2}$ & 0.402 & 0.095 & 0.214 \\
$g_{1,2}$ & 0.648 & 0.103 & 0.273 \\
Tucuxi & & & \\
Intercept & -0.627 & 0.530 & - \\
$S$ & 0.574 & 0.226 & - \\
$X$ & -0.010 & 0.005 & - \\
$g_{1}$ & 0.552 & 0.077 & 0.139 \\
$g_{2}$ & 0.550 & 0.077 & 0.139 \\
$g_{1,2}$ & 0.788 & 0.087 & 0.111 \\
\hline
\end{tabular}




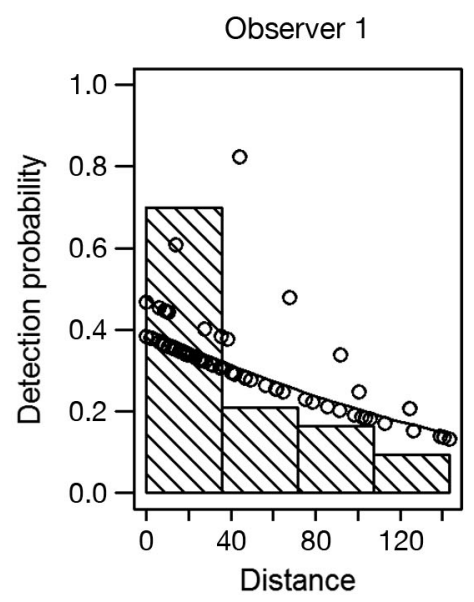

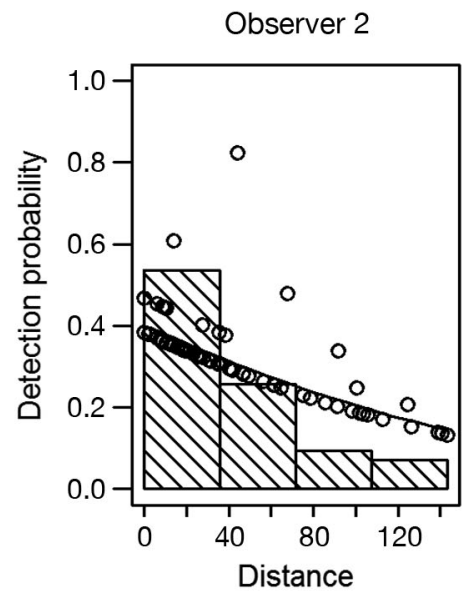

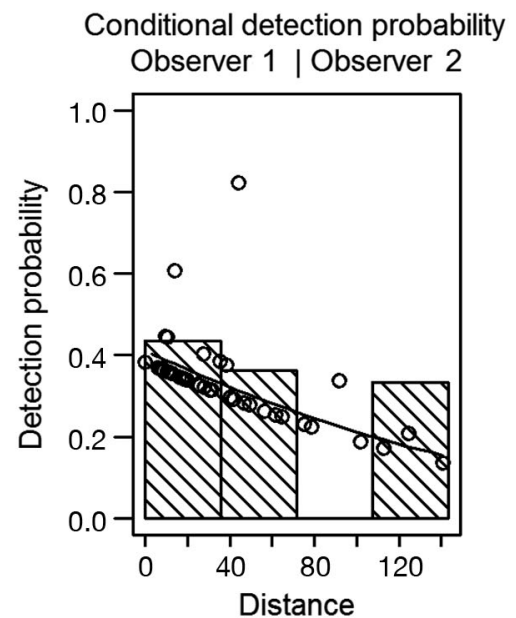

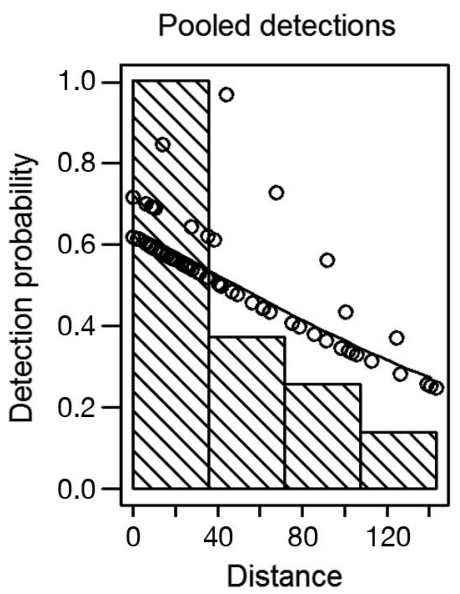

Conditional detection probability Observer 2 | Observer 1

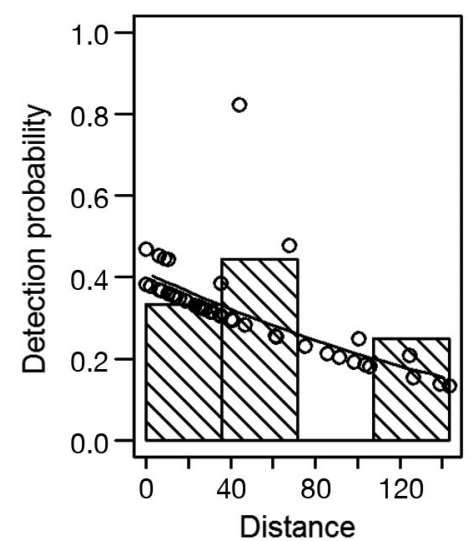

Fig. 3. Detection function for boto Inia geoffrensis; points are the detection probability for each sighting given its perpendicular distance $(\mathrm{m})$ and covariate group size; lines are the fitted half-normal models. Observer 1 corresponds to the fore platform and Observer 2 corresponds to the aft platform

interpretation of our results. We then compare our results to those found in other studies while evaluating ecological and behavioral differences between species. Finally, we discuss the impact of dams and associated threats on river dolphins.

\section{Modeling issues}

Usually, river dolphin data are gathered and analyzed as strip width transects (i.e. census) and crosschannel line transects using standard DS methods (conventional DS, Buckland et al. 2001) (e.g. Vidal et al. 1997, Aliaga-Rossel 2002, Martin \& da Silva 2004). An innovative approach was created by GomezSalazar et al. (2012a), where a double-platform configuration was implemented in order to estimate the detection probability on the trackline through the Petersen estimator (Petersen 1896). In addition, the detection probability fitted to cross-channel transects was used to correct for the groups missed in strip transects. Gomez-Salazar et al. (2012a) avoided using strip transect perpendicular distances to estimate the detection probability because river dolphin groups are not usually distributed at random in relation to the transect design, as confirmed by the authors' observation of a decreasing density gradient from the margin beyond $200 \mathrm{~m}$ towards the river channel (Gomez-Salazar et al. 2012a).

Even if animals are not uniformly distributed in relation to transects, as occurs here, double-observer coupled with DS methods can be used to estimate animal abundance (Laake \& Borchers 2004). For example, for a species that inhabits a narrow strip that can be contained entirely within the covered region, it is not practical to place transects across the strip, because transects along the center of the strip with a double-platform design may give unbiased 

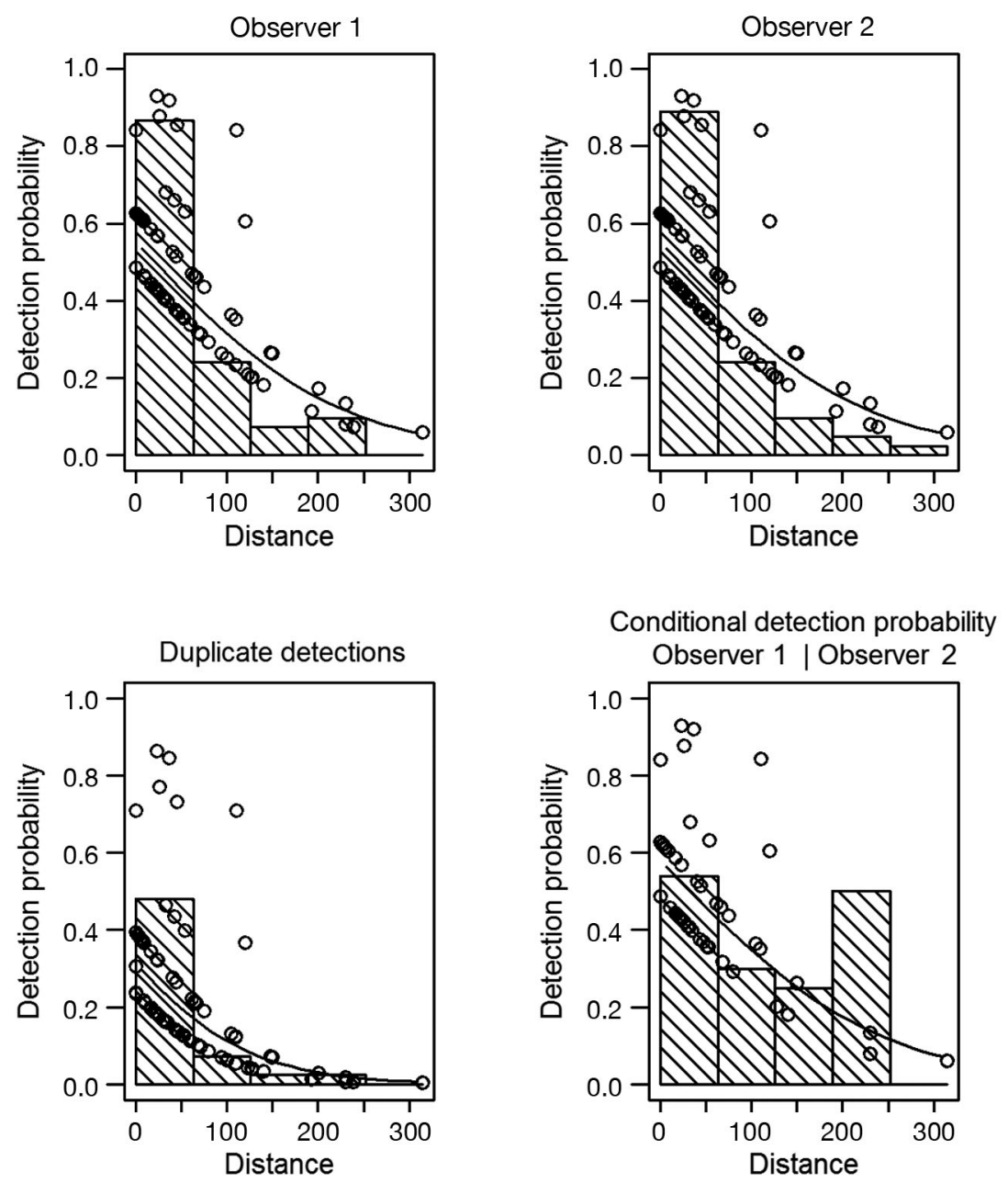
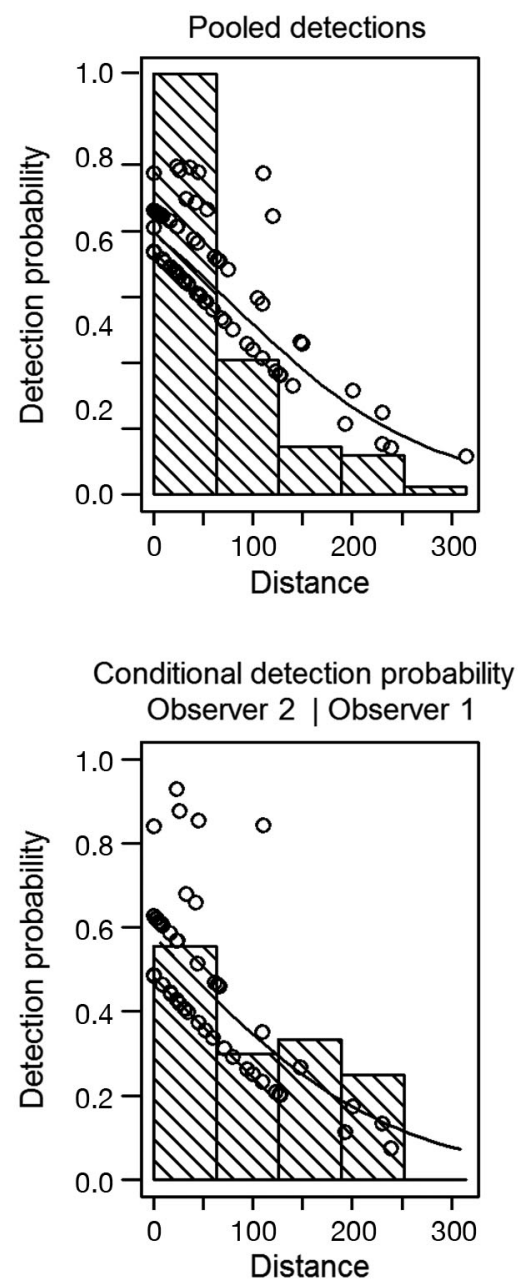

Fig. 4. As in Fig. 3, but for tucuxi Sotalia fluviatilis

estimates of abundance (Laake \& Borchers 2004). Here, we use the term 'narrow strip' to refer to the band up to $300 \mathrm{~m}$ from the river margin. Thus, we were able to fit a detection function and assign a detection history using the same observers (reducing perception bias, which strongly depends on observers), instead of using the detection function fitted only to cross-channel transects from different surveys (as in Gomez-Salazar et al. 2012a). In addition, another advantage of our approach is the incorporation of covariates in both processes (MR and DS). Besides providing unbiased estimates compared to pooled data (Marques \& Buckland 2003), this enables an evaluation of which aspects are more important for the detection of dolphins. Although it was not possible to navigate in the center of the river most of the time because of its large width, we conducted zigzag transects, and thus we are confident that the MRDS model was adequately used in the close-to-themargin and cross-channel transects.
The only previous $g(0)$ values available for boto and tucuxi are $0.947(\mathrm{CV}=0.025)$ and $0.997(\mathrm{CV}=$ 0.003), respectively (Gomez-Salazar et al. 2012a), and were estimated taking into account doubleplatform surveys carried out in many rivers from the Amazon and Orinoco basins. The $g(0)$ values estimated in our study were $0.648(\mathrm{CV}=0.273)$ and $0.788(\mathrm{CV}=0.111)$, meaning that $\sim 35 \%$ of groups of boto and $\sim 21 \%$ of tucuxi were not detected on the trackline. The large difference between both estimates could be a consequence of the smaller detection history of the present study when compared to the study of Gomez-Salazar et al. (2012a) (evidenced by the largest CV), and by the river type, since clear waters were not included in the first $g(0)$ estimate. In order to investigate the effect of water type on the detectability of river dolphins, a large double-platform dataset should be used to estimate $g(0)$ separately for each type of water. 
Table 3. Population estimates of boto Inia geoffrensis and tucuxi Sotalia fluviatilis (by stratum and overall) and summarizing encounter rate (ER), expected group size $(E(s))$, density $(\hat{D})$, abundance $(\hat{N})$, standard error (SE), coefficient of variation $(\mathrm{CV})$ and area of inference $\left(\mathrm{km}^{2}\right)$. (-) no information available

\begin{tabular}{|lcccrrrrr|}
\hline Stratum & ER & $E(s)$ & $\hat{D}$ & $\hat{N}$ & SE & CV & Area \\
\hline Boto & & & & & & & \\
River margin & 0.119 & 1.256 & 0.879 & 783.785 & 251.903 & 0.321 & 891.548 \\
River channel & 0.039 & 1.000 & 0.322 & 943.640 & 582.953 & 0.618 & 2925.452 \\
Channel & 0.229 & 1.039 & 1.859 & 53.530 & 20.531 & 0.383 & 28.792 \\
Island & 1.223 & 2.617 & 5.739 & 19.712 & 12.221 & 0.621 & 3.435 \\
Tributary & 0.335 & 1.170 & 2.595 & 13.933 & 8.183 & 0.587 & 5.370 \\
Lake & 0.000 & - & 0.000 & 0.000 & 0.000 & 0.000 & 5.321 \\
Confluence & 0.000 & - & 0.000 & 53.530 & 0.000 & 0.000 & 3.801 \\
Total & 0.150 & 1.107 & 0.470 & 1814.602 & 719.821 & 0.397 & 3863.719 \\
Tucuxi & & & & & & & \\
River margin & 0.251 & 1.600 & 0.850 & 758.262 & 266.803 & 0.352 & 891.548 \\
River channel & 0.365 & 1.395 & 1.439 & 2562.687 & 1104.286 & 0.431 & 1780.858 \\
Channel & 0.563 & 1.903 & 1.574 & 45.331 & 18.035 & 0.398 & 28.792 \\
Island & 0.437 & 1.592 & 1.632 & 5.605 & 5.206 & 0.929 & 3.435 \\
Tributary & 0.000 & - & 0.000 & 0.000 & 0.000 & 0.000 & 5.370 \\
Lake & 0.000 & - & 0.000 & 0.000 & 0.000 & 0.000 & 5.321 \\
Confluence & 0.000 & - & 0.000 & 0.000 & 0.000 & 0.000 & 3.801 \\
Total & 0.303 & 1.426 & 1.240 & 3371.885 & 1287.900 & 0.382 & 2719.125 \\
\hline
\end{tabular}

servers, including a correction factor (Zhao et al. 2008), or implementing a fixed visual guide displaying distance intervals (bins) in the vessel, as used in aerial surveys (Laake et al. 2008, Bolduc \& Desbiens 2011); (3) estimate availability bias (Marsh \& Sinclair 1989), i.e. the portion of non-detected animals that were not available at the surface during the sample window.

\section{River dolphin ecology}

In this study we confirmed the occurrence limit of tucuxi to be downstream of the São Luiz do Tapajós rapids and also corroborated the occurrence of boto upstream of those rapids, as reported by G. Melo-Santos et al. (unpubl. data). Hence, our results disagree with the current IUCN map of occurrence of both species (Secchi 2012,

Despite several advances in survey and analysis achieved in this work and several other studies (e.g. Martin \& da Silva 2004, Gomez-Salazar et al. 2012a), much effort is still necessary in order to accomplish reliable abundance estimates. We suggest the following approaches: (1) obtain representative $n$ and sample distances on river channels, which are usually sub-sampled due to navigation impediments; (2) perform calibration of distance estimates by ob-

Table 4. Potential biological removal (PBR) limits for boto Inia geoffrensis and tucuxi Sotalia fluviatilis calculated with different minimum population sizes $\left(\hat{N}_{\min }\right)$ obtained as percentiles of a log-normal distribution based on the point abundance and CV estimates from mark-recapture distance sampling

\begin{tabular}{|lll|}
\hline Percentiles & $\hat{N}$ & PBR \\
\hline Boto & & \\
10 & 1111 & 11 \\
20 & 1315 & 13 \\
30 & 1484 & 15 \\
40 & 1646 & 16 \\
50 & 1815 & 18 \\
Tucuxi & & \\
10 & 2101 & 21 \\
20 & 2471 & 25 \\
30 & 2778 & 28 \\
40 & 3069 & 31 \\
50 & 3372 & 34 \\
\hline
\end{tabular}

Reeves et al. 2013), and highlight new occurrence areas. Therefore, this update should be added to the 'geographic range' reported by the IUCN.

We noticed differences between the parameters 'density' and 'abundance' for both species. In river channels, the density of tucuxi was higher than that of boto. This may be explained by the swimming ability of tucuxi, which enables the species to use areas of high water flow such as river channels (Martin et al. 2004). On the other hand, the paucity of boto in larger channels may be explained by the availability of non-permanent flooded habitats such as small streams and flooded forests (known as igarapés and igapós), as well as small tributaries and waters surrounding islands, which may have high densities of prey resources (Martin et al. 2004). Adaptations in the boto skeleton (unfused cervical vertebrae, independent movements of the flippers, flexible vertebral column, and backward swimming) may explain the success of the species in exploring igarapés and igapós (Best \& da Silva 1989, 1993). These facts indicated that, despite being sympatric, the 2 species use the habitat in a partitioned form.

We did not record dolphins in the habitats 'lake' and 'confluence' in the surveyed period, where they were expected to be found (Martin \& da Silva 2004, Trujillo et al. 2010, Gomez-Salazar et al. 2012a, Pavanato et al. in press). The 4 confluences sampled in the Tapajós River correspond to less than $1 \%$ of the total area of inference ('area' in Table 3), which 
may explain the small occurrence probability. On the other hand, the only lake surveyed in the Tapajós River basin, despite its large size, is a popular tourism resort, and therefore, may explain the absence of river dolphins (Gomez-Salazar et al. 2012c).

In this study, density for both species was lower compared to population density estimates along other rivers (e.g. Vidal et al. 1997, Aliaga-Rossel 2002, Martin \& da Silva 2004, Gomez-Salazar et al. 2012a, Pavanato et al. in press). In spite of the difference in the analytical methods between the estimates and the survey season, our results suggest that river dolphin density in clear waters may be lower than in other water types. Because they contain few suspended particles, nutrients, and consequently biomass, clear waters may be less productive than white and black waters (Sioli 1984). Another hypothesis to explain the lower dolphin density in the Tapajós River is related to the period of the survey, immediately after the higher water levels, when igarapés and igapós are still available to river dolphins (mainly boto; Martin et al. 2004); these habitats were not sampled in this study. In addition, the Tapajós River is among the widest in the Amazon basin, which may reduce dolphin detectability when dolphins are in the main river channel.

Results of the MR model suggest behavioral differences between species. While tucuxi is a conspicuous species presenting a variety of aerial behaviors (Best \& da Silva 1993, da Silva \& Best 1996, Flores \& da Silva 2009), allowing detection from the fore and aft sighting platforms, the number of duplicate sightings of boto was lower, resulting in a smaller detection probability. This may be due to the fact that during breathing only a small part of the boto's melon or dorsum emerges (Best \& da Silva 1989, 1993). In addition, the smaller group size of boto compared with tucuxi (Gomez-Salazar et al. 2012b, Santos et al. 2012) can increase the perception bias, particularly at greater distances.

\section{Impact of dams and associated risk factors}

River dolphins are the most threatened species of cetaceans due to the transformation of their habitat (Reeves \& Leatherwood 1994). With increases in human populations, resource consumption increases, and the situation for river dolphins is likely to become worse (Reeves \& Martin 2009). The Tapajós River is an example of this scenario, where fishing, boat traffic, mining activities, and hydroelectric dams constitute serious threats for river dolphin populations.
Regarding the removal rate, if the human-caused removal is lower than the PBR, the depleted population will be able to recover at least to half of its carrying capacity. This is not the case of many coastal cetaceans subjected to a series of human threats, especially incidental mortality from interactions with fishing gear (Williams et al. 2008, Fruet et al. 2010, Read 2013). The disruption of the river flow and the blocking of the rapids might isolate more individuals in one portion of the river than the hypothetical PBR of 11 to 18 boto estimated in this study. It can be even worse between the Jatobá and Chacorão dams (stretch 2), where the mean encounter rates of boto were significantly lower than those found downstream the São Luiz do Tapajós rapids (stretch 1: 0.82 ind. $\mathrm{km}^{-2}, \mathrm{SE}=0.1$; stretch 2: 0.52 ind. $\mathrm{km}^{-2}, \mathrm{SE}=$ 0.09). Although the results obtained via PBR should be interpreted with caution, we suggest that this level of population fragmentation is not sustainable at any $\hat{\mathbf{N}}_{\min }$, at least for botos upstream of the São Luiz do Tapajós rapids, numbers of which will decline rapidly.

In the case of tucuxi, fragmentation seems not to be a concern, since this population is not present upstream of the São Luiz do Tapajós rapids. Nevertheless, the construction of dams poses and increases potential threats, such as enhancement of mercury effects on the environment, habitat degradation, and depletion of prey (Kondolf 1997, Smith 1998, Boudou et al. 2005, Stickler et al. 2013), all of which are factors that can be sub-lethal or lethal at the individual level.

A specific solution to avoid the isolation of river dolphin subpopulations is the building of 'swimways,' which may allow the movement of individuals down- and upstream of the dams. Nevertheless, there is a danger that river dolphins will use the corridor only for downstream transport, thus contributing to the decrease of the population in the upper reaches of the river, which can lead to local extinction (Reeves \& Leatherwood 1994).

The ecological role of cetaceans is usually related to their high abundance, high trophic status, and high metabolic rates, using significant proportions of the primary production of their ecosystems (Estes et al. 2006). If top predators decline, several trophic levels may be impacted, with effects playing out over large spatial and temporal scales. With the loss of a top predator, the meso-consumer community tends to increase and the prey species are likely to decrease (Heithaus et al. 2008). In the case of Tapajós River, the removal of boto upstream from the dam can lead to an increment of boto prey with a consequent 
decrease of species at lower trophic levels, including primary producers. This may lead to a quick depletion of dissolved oxygen which, in turn, may affect the meso-consumer community.

The Federal Government of Brazil has an extensive plan to construct 58 hydroelectric dams in the Amazon basin to meet the growing demands for energy in Brazil (Kahn et al. 2014). The initiative is even stronger in face of the current energy issues in the southeastern region of Brazil. Hence, the 3 dams planned along the Tapajós River, added to those under construction, in an inventory, or in planning in tributary rivers such as the Juruena, Teles Pires, and Jamanxim (International Rivers 2015), only represent the proverbial tip of the iceberg.

Our study is only the starting point of a monitoring program of river dolphins in the Tapajós River basin. Long-term studies, covering the upper Tapajós River as well as its tributaries (Juruena, Teles Pires, and Jamanxim), with the aim of identifying population trends and status are urgently needed in face of the planned dam construction. However, we should be aware that census and DS methods are not likely to detect early signs of population decline before a critical level is reached (Gerrodette 1987, Wade 1998, Huang et al. 2012). In addition to visual methods, genetic studies are fundamental to establish the population connection between rapids, which should elucidate the true impact of the dams on the viability of subpopulations.

We have highlighted throughout this study the impacts, risks, and possible changes in ecological features likely to arise for South American river dolphins if the dams become a reality. Thereby, precautionary measures are of the utmost importance and should be taken before the construction of any hydroelectric dams in the Tapajós River basin. These include a detailed re-evaluation regarding the dam location in relation to the rapids, as well as the need to use all available waterfalls for efficiency in energy generation. As a final remark, for the first time prior to a dam construction project, we have the opportunity to engage in a thoughtful discussion of the impacts that dams have on river dolphins, instead of opting for mitigation and remediation procedures after the fact. In order that the re-evaluation proposed here reaches other segments of society, the construction of the São Luiz do Tapajós dam should be postponed.

Acknowledgements. We acknowledge the World Wildlife Fund (WWF) for their strong support of this project as a contribution to ongoing efforts to highlight the impacts of dam construction in the Amazon River basin. We are grateful to
Eliane Oliveira for GIS information and Daniel E. Pendleton for detailed English editing. We also acknowledge 2 anonymous reviewers for their valuable comments which substantially improved the quality of this manuscript. This study was funded by the Ministério da Ciência, Tecnologia e Inovação (MCTI) through Mamirauá Institute for Sustainable Development, with support from the Omacha Foundation (Colombia) and Whitley Fund for Nature. The Conselho Nacional de Desenvolvimento Científico e Tecnológico (CNPq) provided a scholarship to H.J.P., who worked under the guidance of M.M.

\section{LITERATURE CITED}

Aliaga-Rossel E (2002) Distribution and abundance of the river dolphin (Inia geoffrensis) in the Tijamuchi River, Beni, Bolivia. Aquat Mamm 28:312-323

Araújo CC, da Silva VMF (2014) Spatial distribution of river dolphins, Inia geoffrensis (Iniidae), in the Araguaia River (central Brazil). Mammalia 78:481-486

* Araújo CC, Wang JY (2012) Botos (Inia geoffrensis) in the upper reaches of the Tocantins river (central Brazil) with observations of unusual behavior, including object carrying. Aquat Mamm 38:435-440

Best RC, da Silva VMF (1989) Amazon River dolphin, boto. Inia geoffrensis (de Blainville, 1817). In: Ridgway $\mathrm{SH}$, Harrison RJ (eds) Handbook of marine mammals, Book 4. Academic Press, London, p 1-23

Best RC, da Silva VMF (1993) Inia geoffrensis. Mamm Species 426:1-8

Bolduc F, Desbiens A (2011) Delineating distance intervals for ship-based seabird surveys. Waterbirds 34:253-257

* Boudou A, Maury-Brachet R, Coquery M, Durrieu G, Cossa D (2005) Synergic effect of gold mining and damming on mercury contamination in fish. Environ Sci Technol 39: 2448-2454

Braulik GT, Noureen U, Arshad M, Reeves RR (2015) Review of status, threats, and conservation management options for the endangered Indus River blind dolphin. Biol Conserv 192:30-41

Buckland ST, Anderson DR, Burnham KP, Laake JL, Borchers DL, Thomas L (2001) Introduction to distance sampling. Oxford University Press, Oxford

Buckland ST, Anderson DR, Burnham KP, Laake JL, Borchers DL, Thomas L (2004) Advanced distance sampling. Oxford University Press, Oxford

Burnham KP, Anderson DR (2002) Model selection and multimodel inference: a practical information-theoretic approach. Springer Science+Business Media, New York, NY

da Silva VMF, Best RC (1996) Sotalia fluviatilis. Mamm Species 527:1-7

da Silva VMF, Martin AR (2010) Status, threats, conservation initiatives and possible solutions for Inia geoffrensis and Sotalia fluviatilis in Brazil. In: Trujillo F, Crespo E, van Damme PA, Usma JS (eds) The action plan for South American river dolphins 2010-2020. WWF, Fundación Omacha, WDS, WDCS, Solamac, Bogota

*Dudgeon D (1992) Endangered ecosystems: a review of the conservation status of tropical Asian rivers. Hydrobiologia 248:167-191

* Dudgeon D (2005) Last chance to see: ex situ conservation and the fate of baiji. Aquat Conserv 15:105-108

Estes JA, DeMaster DP, Brownell RL, Doak DF, Williams TM 
(2006) Retrospection and review. In: Estes JA, DeMaster DP, Doak DF, Williams TM, Brownell RL (eds) Whales, whaling and ocean ecosystems. University of California Press, Berkeley, CA, p 388-393

FAO (Food and Agriculture Organization of the United Nations) (2001) Dams, fish and fisheries: opportunities, challenges and conflict resolution. Fish Tech Pap 419. FAO, Rome

Fearnside PM (2015) Amazon dams and waterways: Brazil's Tapajós basin plans. Ambio 44:426-439

Flores PAC, da Silva VMF (2009) Tucuxi and Guiana dolphin. In: Perrin WF, Würsig B, Thewissen JGM (eds) Encyclopedia of marine mammals. Academic Press, San Diego, CA, p 1188-1192

Fruet PF, Kinas PG, Silva KG, Di Tullio JC and others (2010) Temporal trends in mortality and effects of by-catch on common bottlenose dolphins, Tursiops truncatus, in southern Brazil. J Mar Biol Assoc UK 92(8):1865-1876

Gerrodette T (1987) A power analysis for detecting trends. Ecology 68:1364-1372

KGerrodette T, DeMaster DP (1990) Quantitative determination of optimum sustainable population level. Mar Mamm Sci 6:1-16

* Gomez-Salazar C, Trujillo F, Portocarrero-Aya M, Whitehead H (2012a) Population, density estimates, and conservation of river dolphins (Inia and Sotalia) in the Amazon and Orinoco river basins. Mar Mamm Sci 28:124-153

Gomez-Salazar C, Trujillo F, Whitehead H (2012b) Ecological factors influencing group sizes of river dolphins (Inia geoffrensis and Sotalia fluviatilis). Mar Mamm Sci 28: 124-142

* Gomez-Salazar C, Coll M, Whitehead H (2012c) River dolphins as indicators of ecosystem degradation in large tropical rivers. Ecol Indic 23:19-26

Goulding M, Barthem R, Ferreira E (2003) The Smithsonian atlas of the Amazon. Princeton Editorial Associates, Hong Kong

Gravena W, Farias IP, da Silva MNF, da Silva VMF, Hrbek T (2014) Looking to the past and the future: Were the Madeira River rapids a geographical barrier to the boto (Cetacea: Iniidae)? Conserv Genet 15:619-629

* Heithaus MR, Frid A, Wirsing AJ, Worm B (2008) Predicting ecological consequences of marine top predator declines. Trends Ecol Evol 23:202-210

Horvitz DG, Thompson DJ (1952) A generalization of sampling without replacement from a finite universe. J Am Stat Assoc 47:663-685

Hrbek T, da Silva VMF, Dutra N, Gravena W, Martin AR, Farias IP (2014) A new species of river dolphin from Brazil or: how little do we know our biodiversity. PLOS ONE 9:e83623

* Huang SL, Hao Y, Mei Z, Turvey S, Wang D (2012) Common patterns of population decline for freshwater cetacean species in deteriorating habitats. Freshw Biol 57: 1266-1276

* Innes S, Heide-Jørgensen MP, Laake JL, Laidre KL, Cleator HJ, Richard P, Stewart REA (2002) Surveys of belugas and narwhals in the Canadian High Arctic in 1996. NAMMCO Sci Publ 4:169-190

International Rivers (2015) The state of the world's rivers. www.internationalrivers.org (accessed 29 August 2015)

Junk WJ, Piedade MTF, Schöngart J, Wittmann F (2012) A classification of major natural habitats of Amazonian white-water river floodplains (várzeas). Wetlands Ecol Manag 20:461-475
Kahn JR, Freitas CE, Petrere M (2014) False shades of green: the case of Brazilian Amazonian hydropower. Energies 7 : 6063-6082

Kondolf GM (1997) Hungry water: effects of dams and gravel mining on river channels. Environ Manag 21: 533-551

* Kondolf GM, Gao Y, Annandale GW, Morris GL and others (2014) Sustainable sediment management in reservoirs and regulated rivers: experiences from five continents. Earth's Future 2:256-280

Laake JL, Borchers DL (2004) Methods for incomplete detection at zero distance. In: Buckland ST, Anderson DR, Burnham KP, Laake JL, Borchers DL, Thomas L (eds) Advanced distance sampling. Oxford University Press, Oxford, p 108-189

*Laake J, Guenzel RJ, Bengtson JL, Boveng P, Cameron M, Hanson MB (2008) Coping with variation in aerial survey protocol for line-transect sampling. Wildl Res 35: 289-298

Laake J, Borchers D, Thomas L, Miller D, Bishop J (2015) mrds: mark-recapture distance sampling. R package version 2.1.14. https://CRAN.R-project.org/package=mrds

Luz-Agostinho KDG, Agostinho AA, Gomes LC, Júlio JF Jr (2008) Influence of flood pulses on diet composition and trophic relationships among piscivorous fish in the upper Paraná River floodplain. Hydrobiologia 607:187-198

*Marques FFC, Buckland ST (2003) Incorporating covariates into standard line transect analyses. Biometrics 59: 924-935

* Marsh H, Sinclair DF (1989) Correcting for visibility bias in strip transect aerial surveys of aquatic fauna. J Wildl Manag 53:1017-1024

Martin AR, da Silva VMF (2004) River dolphins and flooded forest: seasonal habitat use and sexual segregation of boto (Inia geoffrensis) in an extreme cetacean environment. J Zool 263:295-305

Martin AR, da Silva VMF, Salmon DL (2004) Riverine habitat preferences of botos (Inia geoffrensis) and tucuxis (Sotalia fluviatilis) in the Central Amazon. Mar Mamm Sci 20:189-200

McCully P (2001) Silenced rivers: the ecology and politics of large dams. Zed Books, London

*Paudel S, Timilsina YP, Lewis J, Ingersoli T, Jnawali SR (2015) Population status and habitat occupancy of endangered river dolphins in the Karnali River system of Nepal during low water season. Mar Mamm Sci 31: 707-719

Pavanato HJ, Gomez-Salazar C, Trujillo F, Lima D, Paschoalini M, Ristau N, Marmontel M (in press) Density, abundance and group size of river dolphins (Inia geoffrensis and Sotalia fluviatilis) in central Amazonia, Brazil. J Cetacean Res Manag

Petersen CGJ (1896) The yearly immigration of young plaice into the Limfjord from the German Sea. Rep Dan Biol Stn $6: 1-48$

Portocarrero-Aya M, Ferrer A, Lasso CA, Ruiz-García M, Bolaños-Jiménez J, Caballero S (2010) Status, distribution and conservation of the river dolphins Inia geoffrensis and Sotalia spp. in Venezuela. In: Trujillo F, Crespo E, van Damme PA, Usma JS (eds) The action plan for South American river dolphins 2010-2020. WWF, Fundación Omacha, WDS, WDCS, Solamac, Bogota, p 17-28

R Core Team (2015) R: a language and environment for statistical computing. R Foundation for Statistical Computing, Vienna 
Read AJ (2013) Development of conservation strategies to mitigate the bycatch of harbor porpoises in the Gulf of Maine. Endang Species Res 20:235-250

Reeves RR, Leatherwood S (1994) Dams and river dolphins: Can they co-exist? Ambio 23:172-175

Reeves RR, Martin AR (2009) River dolphins. In: Perrin WF, Würsig B, Thewissen JGM (eds) Encyclopedia of marine mammals. Academic Press, San Diego, CA, p 976-979

Reeves RR, Smith BD, Kasuya T (2000) Biology and conservation of freshwater cetaceans in Asia. IUCN, Gland

Reeves RR, Jefferson TA, Karczmarski L, Laidre K and others (2013) Inia geoffrensis. www.iucnredlist.org (accessed 30 August 2015)

Rosenberg DM, Berkes F, Bodaly RA, Hecky RE, Kelly CA, Rudd JWM (1997) Large-scale impacts of hydroelectric development. Environ Rev 5:27-54

Sabir MA, Shafiq-Ur-Rehman S, Umar M, Waseem A, Farooq M, Khan AR (2013) The impact of suspended sediment load on reservoir siltation and energy production: a case study of the Indus river and its tributaries. Pol J Environ Stud 22:219-225

Santos GMA, Quaresma AC, Barata RR, Martins BML, Siciliano S, Silva JS Jr, Emin-Lima R (2012) Etho-ecological study of the Amazon River dolphin, Inia geoffrensis (Cetacea: Iniidade) and the dolphins of genus Sotalia (Cetacea: Delphinidae) in Guamá River, Amazonia. Mar Biodivers Rec 5:e23

Santos GMA, Rodrigues ALF, Arcoverde DL, Ramos I, Sena L, Silva ML (2014) Unusual records of the behavior of boto Inia sp. (Cetartiodactyla, Iniidae) in the lower reaches of the Tocantins and Guamá River, Amazônia. In: Samuels JB (ed) Dolphins: ecology, behavior and conservation strategies. Nova Science Publishers, New York, NY, p 1-17

Secchi E (2012) Sotalia fluviatilis. www.iucnredlist.org (accessed 30 August 2015)

Sioli H (1984) The Amazon and its main affluents: hydrography, morphology of the river courses, and river types. In: Sioli H (ed) The Amazon: limnology and landscape ecology of a mighty tropical river and its basin. Dr. W. Junk Publishers, Dordrecht, p 127-165

Smith BD (1998) River dolphins in Bangladesh: conservation

Editorial responsibility: Ana Cañadas,

Madrid, Spain and the effects of water development. Environ Manag 22:323-335

Smith BD, Braulik GT (2012) Platanista gangetica. www. iucnredlist.org (accessed 11 September 2015)

Smith BD, Reeves RR (2012) River cetaceans and habitat change: generalist resilience or specialist vulnerability? J Mar Biol 2012:718935

Smith BD, Zhou K, Wang D, Reeves RR, Barlow J, Taylor BL, Pitman R (2008) Lipotes vexillifer. www.iucnredlist.org (accessed 11 September 2015)

Stickler CM, Coe MT, Costa MH, Nepstad DC and others (2013) Dependence of hydropower energy generation on forests in the Amazon Basin at local and regional scales. Proc Natl Acad Sci USA 110:9601-9606

Taylor BL, DeMaster DP (1993) Implications of non-linear density dependence. Mar Mamm Sci 9:360-371

Trujillo F, Crespo E, van Damme PA, Usma JS (2010) The action plan for South American river dolphins 2010-2020. WWF, Fundación Omacha, WDS, WDCS, Solamac, Bogota

Turvey ST, Pitman RL, Taylor BL, Barlow J and others (2007) First human-caused extinction of a cetacean species? Biol Lett 3:537-540

* Vidal O, Barlow J, Hurtado LA, Torre J, Cendón P, Ojeda Z (1997) Distribution and abundance of the Amazon river dolphin (Inia geoffrensis) and the tucuxi (Sotalia fluviatilis) in the upper Amazon River. Mar Mamm Sci 13:427-445

*Wade PR (1998) Calculating limits to the allowable humancaused mortality of cetaceans and pinnipeds. Mar Mamm Sci 14:1-37

Williams R, Hall A, Winship A (2008) Potential limits to anthropogenic mortality of small cetaceans in coastal water of British Columbia. Can J Fish Aquat Sci 65: $1867-1878$

Zhang X, Wang D, Liu R, Wei Z and others (2003) The Yangtze River dolphin or baiji (Lipotes vexillifer): population status and conservation issues in the Yangtze River, China. Aquat Conserv 13:51-64

Z Zhao X, Barlow J, Taylor BL, Pitman RL and others (2008) Abundance and conservation status of the Yangtze finless porpoise in the Yangtze River, China. Biol Conserv 141:3006-3018

Submitted: October 1, 2015; Accepted: July 23, 2016

Proofs received from author(s): September 10, 2016 